Published in final edited form as:

Immunol Res. 2014 May ; 58(0): 387-393. doi:10.1007/s12026-014-8492-5.

\title{
Leukotrienes in pulmonary arterial hypertension
}

\author{
Wen Tian, \\ VA Palo Alto Health Care System, Stanford University, Med111P, 3801 Miranda Ave., Palo Alto, \\ CA 94304, USA
}

\section{Xinguo Jiang,}

VA Palo Alto Health Care System, Stanford University, Med111P, 3801 Miranda Ave., Palo Alto, CA 94304, USA

\section{Yon K. Sung,}

VA Palo Alto Health Care System, Stanford University, Med111P, 3801 Miranda Ave., Palo Alto, CA 94304, USA

\section{Jin Qian,}

VA Palo Alto Health Care System, Stanford University, Med111P, 3801 Miranda Ave., Palo Alto, CA 94304, USA

Ke Yuan, and

Stanford University School of Medicine, Stanford, CA 94305, USA

Mark R. Nicolls

VA Palo Alto Health Care System, Stanford University, Med111P, 3801 Miranda Ave., Palo Alto, CA 94304, USA

\section{Abstract}

Leukotrienes (LTs) are lipid mediators derived from the 5-lipoxygenase (5-LO) pathway of arachidonic acid metabolism and are markers and mediators of pulmonary inflammation. Research over the past two decades has established that LTs modulate inflammation in pulmonary arterial hypertension (PAH). The purpose of this review was to summarize the current knowledge of LTs in the pathophysiology of PAH and to highlight a recent study that advances our understanding of how leukotriene $\mathrm{B}_{4}\left(\mathrm{LTB}_{4}\right)$ specifically contributes to pulmonary vascular remodeling. The results of these studies suggest that pharmacological inhibition of LT pathways, especially $\mathrm{LTB}_{4}$, has high potential for the treatment of PAH.

\section{Keywords}

Leukotriene; Pulmonary arterial hypertension; Vascular remodeling; Inflammation; 5Lipoxygenase

(C) Springer Science+Business Media New York 2014

M. R. Nicolls mnicolls@stanford.edu.

Conflict of interest WT and MRN and Stanford University (OTL \#S11-438) have a patent pending concerning the use of LTB4 antagonists for the treatment of PAH. 


\section{Introduction}

Pulmonary arterial hypertension (PAH) is a life-threatening disease characterized by vasoconstriction and vascular remodeling that result in increased pulmonary vascular resistance and pulmonary arterial pressure [1-3]. Advances in the understanding of the pathobiology of PAH have led to the development of a number of effective vasodilating therapies, such as endothelin receptor antagonists, phosphodiesterase type 5 inhibitors, and prostacyclin or analogs. However, even in the current treatment era, the average life expectancy of patients with PAH remains poor and is estimated to be 5-7 years after diagnosis [4]; new approaches are clearly needed. Perivascular inflammation is common in PAH and is characterized by the presence of various immune cells, including T cells, B cells, plasma cells, mast cells, dendritic cells, and macrophages, as well as inflammatory molecules, such as cytokines, chemokines, growth factors, eicosanoids, reactive oxygen, and nitrogen species $[5,6]$. Recent preclinical studies demonstrate that abnormal regulatory $\mathrm{T}$ cell (Treg) activity exacerbates inflammation associated with pulmonary vascular injury and facilitates disease development [7, 8]. In PAH arising in conditions associated with immune dysregulation, the role of leukotrienes (LTs) appears to be an exciting new target for disease intervention that could complement conventional vasodilator therapy.

LTs are lipid mediators derived from the polyunsaturated fatty acid and arachidonic acid. Their function is in initiating and amplifying both the innate and adaptive immune responses by regulating the recruitment and activation of leukocytes in inflamed tissues $[9,10]$. In this review, we will discuss the current understanding of how LTs are involved in several aspects of the pathogenesis of PAH.

\section{Overview of LT synthesis and actions}

LTs are synthesized primarily in leukocytes at the Golgi apparatus and endoplasmic reticulum (ER)/nuclear membrane. At these sites, activated phospholipase A2 (PLA $)$, especially cytosolic PLA $\mathrm{A}_{2}$, hydrolyzes membrane phospholipids and liberates arachidonic acid from the membrane bilayer. 5-LO in the cytosol or nucleus is subsequently activated and translocates to the inner and outer nuclear membrane initiating the synthesis of LTs by converting arachidonic acid to 5-hydroperoxyeicosatetraenoic acid (5-HPETE) and $\mathrm{LTA}_{4}$. This reaction requires the integral nuclear envelope protein 5-lipoxygenase-activating protein (FLAP) [11-13]. $\mathrm{LTA}_{4}$ has a half-life of less than $3 \mathrm{~s}$ at physiological $\mathrm{pH}$ [14] and is quickly either conjugated to glutathione by $\mathrm{LTC}_{4}$ synthase $\left(\mathrm{LTC}_{4} \mathrm{~S}\right)$ to form $\mathrm{LTC}_{4}$ or hydrolyzed by $\mathrm{LTA}_{4}$ hydrolase $\left(\mathrm{LTA}_{4} \mathrm{H}\right)$ to generate $\mathrm{LTB}_{4}$ [15-19]. Both $\mathrm{LTC}_{4}$ and $\mathrm{LTB}_{4}$ can be transported out of the source cell into the extracellular milieu. $\mathrm{LTB}_{4}$ may also potentially act in the nucleus as a modulator of transcription. $\mathrm{LTC}_{4}$ undergoes sequential peptide cleavage of the glutathione moiety to form $\mathrm{LTD}_{4}$ or $\mathrm{LTE}_{4}$ [20-23]. $\mathrm{LTC}_{4}, \mathrm{LTD}_{4}$, and $\mathrm{LTE}_{4}$, as a group, are named the cysteinyl leukotrienes (CysLTs) (Fig. 1).

Different leukocytes generate different LT profiles: neutrophils synthesize exclusively $\mathrm{LTB}_{4}$ [24, 25], eosinophils, and mast cells predominantly $\mathrm{LTC}_{4}$ [26-30], while macrophages generate both [31-33]. The actions of LTs are mediated through a series of G-proteincoupled receptors. These cell-surface receptors are classified into three groups: receptors for 
$\mathrm{LTB}_{4}$ (BLT1, BLT2), receptors for CysLTs (CysLT1, CysLT2) [34], and a newly discovered receptor specific for $\mathrm{LTE}_{4}$ known as CysLTE [35, 36]. The proinflammatory effects of $\mathrm{LTB}_{4}$ in leukocytes are mainly transduced through the high-affinity receptor, BLT1, while the role of the lower-affinity BLT2 receptor remains unknown. The CysLTs are known to cause long-lived bronchoconstriction mediated by the CysLT1 receptor. This receptor recognizes ligands with the following rank order of the affinity: $\mathrm{LTD}_{4}>\mathrm{LTC}_{4}=$ $\mathrm{LTE}_{4}$. CysLT2 recognizes its ligands with following order of affinity: $\mathrm{LTC}_{4}=\mathrm{LTD}_{4}<\mathrm{LTE}_{4}$ [37-40].

\section{The role of the 5-LO/LT pathway in PAH 5-LO and FLAP expression in animal models and in humans with PAH}

The correlation between 5-LO and PAH was first noted by Voelkel et al. in 1996; they found that both alveolar macrophages and vascular endothelial cells from rats exposed to chronic hypoxia had increased expression of 5-LO [41]. The lungs of chronically hypoxic rats showed increased translocation of 5-LO from the cytosol to the perinuclear membrane, indicating a higher level of 5-LO activation. Treatment with the FLAP inhibitor, MK-886, an antagonist for 5-LO and FLAP interaction, inhibited hypoxia-induced pulmonary vasoconstriction and prevented the development of chronic hypoxic pulmonary hypertension $(\mathrm{PH})$ in rats (By convention, animal models of $\mathrm{PAH}$ are referred to as ' $\mathrm{PH}$ '). Additionally, compared to controls, 5-LO knockout mice exposed to chronic hypoxia had attenuated right ventricle hypertrophy, as measured by the right ventricle (RV) over left ventricle (LV) plus septum $(\mathrm{S})$ ratio $(\mathrm{RV} / \mathrm{LV}+\mathrm{S})$. This was the first study to suggest that 5-LO is involved in the regulation of pulmonary vascular tone and plays a role in the pathogenesis of $\mathrm{PH}$ in chronic hypoxia rodent models.

The Denver group then went on to examine the expression of 5-LO and FLAP in the lungs of patients with PAH. They found that compared to healthy controls, patients with PAH had elevated protein levels of both 5-LO and FLAP demonstrated by immunohistochemistry and increased 5-LO mRNA levels measured by in situ hybridization [42]. 5-LO and FLAP were prominent in alveolar macrophages clustered around plexiform lesions. Additionally, in the lungs of PAH patients, the endothelial cells in plexiform and concentric lesions expressed both 5-LO and FLAP.

While 5-LO overexpression in rat lungs using a recombinant adenovirus expressing 5-LO (Ad5-LO) did not cause $\mathrm{PH}$ in normal rats, it markedly accelerated the progression of $\mathrm{PH}$ in rats treated with monocrotaline (MCT) [43]. An increase in pulmonary artery pressure occurred earlier in the rats treated with MCT + Ad5-LO (7-10 days) compared with those treated with control vector, or MCT alone (15-18 days). Lung tissue histological sections from MCT + Ad5-LO rats exhibited severe inflammation and pulmonary vascular muscularization. Treatment of 5-LO inhibitors, zileuton or MK-886, prevented either MCTor MCT + Ad5-LO induced PH. These data suggested that 5-LO plays a critical role in the progression of $\mathrm{PH}$ in the setting of pulmonary vascular endothelial cell dysfunction [43]. 


\section{BMPR2 and 5-LO in PH}

Heterozygous germline mutations in the bone morphogenetic protein type 2 receptor (BMPR2) account for approximately $80 \%$ of patients with familial PAH [44, 45]. The disease is transmitted in an autosomal dominant fashion, but has only a $20 \%$ penetrance, which suggests that additional triggers are needed to develop the disease. Additionally, it is estimated that $15-40 \%$ of patients with idiopathic PAH may also have mutations in BMPR2 [45-47]. The identification of this genetic mutation in PAH has provided a focus for studying the complex pathobiology of this disease.

Under unstressed conditions, $B M P R 2^{+/-}$mice were found to have the same life span, right ventricular systolic pressure (RVSP), and lung histology as those of wild-type mice. However, intratracheal instillation of Ad5-LO significantly increased the RVSP of $B M P R 2^{+-}$mice compared to the wild-type mice. Also, modest but significant muscularization of distal pulmonary arterioles was discovered 4 weeks after Ad5-LO treatment [48]. This study showed that under the inflammatory insult triggered by 5-LO, $B M P R 2^{+-}$mice were more susceptible to an increase in RVSP and vascular remodeling than wild-type mice, suggesting a critical role for 5-LO in BMPR2 haploinsufficiency and the development of PAH.

\section{$\mathrm{LTB}_{4}$ in PAH}

Several prior observations suggested that $\mathrm{LTB}_{4}$ may contribute to the pathogenesis of $\mathrm{PAH}$. First, $\mathrm{LTB}_{4}$ has long been recognized as a chemoattractant for many inflammatory cell types observed in PAH, such as T and B lymphocytes, macrophages, and neutrophils. Next, it is known that the phosphorylation of 5-LO (on the $\mathrm{Ser}^{271}$ residue by p38 MAPK) significantly increases its enzyme activity in vitro $[49,50]$ and, thus, facilitates 5-LO nuclear retention which favors $\mathrm{LTB}_{4}$ biosynthesis [51, 52]. Indeed, increased $\mathrm{LTB}_{4}$ and myeloperoxidase (MPO) level was observed within 3 days after MCT injection in rats. Administration of ONO4057, a BLT1 antagonist, reduced right ventricular hypertrophy induced by MCT and prevented these animals from developing $\mathrm{PH}$ [53].

Recently, our group showed that in both the SU5416 (SU; a VEGFR2 inhibitor)-treated athymic rat model of severe $\mathrm{PH}$ associated with an absence of $\mathrm{T}$ cell-mediated regulation and in the lungs of PAH patients, the expression of biosynthetic enzymes for $\mathrm{LTB}_{4}$ production, specifically phospho-Ser ${ }^{271} 5-\mathrm{LO}(\mathrm{p} 5-\mathrm{LO})$ and $\mathrm{LTA}_{4} \mathrm{H}$, were elevated compared to controls [54]. p5-LO and $\mathrm{LTA}_{4} \mathrm{H}$ expression were prominent in macrophages around partially or fully occluded small-tomid-sized pulmonary arterioles. Upregulation of these enzymes correlated with high levels of $\mathrm{LTB}_{4}$ in the lung bronchoalveoloar fluid as in the systemic circulation. A detailed morphometric assessment of these macrophages demonstrated that macrophages closest to diseased arterioles had the highest expression of $\mathrm{p} 5$-LO, suggesting that $\mathrm{LTB}_{4}$-producing cells were in close proximity to the site of disease, possibly playing a role in the observed vascular remodeling.

Because pulmonary arterial endothelial cell (PAEC) injury is regarded as an important early event in $\mathrm{PH}$ pathogenesis, we established a macrophage-PAEC co-culture system to determine whether macrophages, specifically p5-LO positive, LTB $_{4}$-producing 
macrophages, could injure adjacent endothelial cells. We found that macrophages isolated from the lungs of SU-treated athymic rats with $\mathrm{PH}$ induced significant endothelial cell apoptosis. Further, macrophages from healthy rats that were transfected with S271E 5-LO, a plasmid that produces a 5-LO phosphorylation mimic mutant, caused marked PAEC death to a similar degree. Furthermore, $\mathrm{LTB}_{4}$ cultured with PAEC alone demonstrated a capacity to injure the cells in a dose-dependent fashion. Blocking BLT1, the major receptor for $\mathrm{LTB}_{4}$ on endothelial cells, prevented $\mathrm{LTB}_{4}$-mediated apoptosis [54].

To explain our findings of $\mathrm{LTB}_{4}$-induced PAEC apoptosis, we hypothesized that $\mathrm{LTB}_{4}$ may be inhibiting a signaling cascade vital to endothelial cell survival, such as the sphingosine 1 phosphate (S1P) —endothelial nitric oxide synthase (eNOS) pathway. S1P is a class of vasoprotective signaling lipids produced by the phosphorylation of sphingosine by sphingosine kinase 1 (Sphk1) and downstream, and activates eNOS [55, 56]. Recent studies of S1P have revealed that this bioactive sphingolipid decreases vascular permeability and promotes endothelial survival through eNOS and prostacyclin [57-59]. In this recent study [54], we showed that $\mathrm{LTB}_{4}$ induced PAEC apoptosis by inhibiting the expression and activation of both Sphk1 and eNOS.

We further demonstrated that $\mathrm{LTB}_{4}$ induced the proliferation and hypertrophy of human pulmonary arterioles smooth muscle cells (PASMC) in a concentration- and BLT1dependent manner [54]. These results are consistent with the established role of $\mathrm{LTB}_{4}$ on other types of vascular smooth muscle cells. For example, $\mathrm{LTB}_{4}$ has been strongly implicated in the process of atherogenesis, and BLT1 expression is increased in atherosclerotic plaques and on smooth muscle cells under inflammatory stress [60]. Thus, $\mathrm{LTB}_{4}$, liberated by activated macrophages, was produced in sufficient concentrations (as gauged by the bronchoalveolar fluid levels) to induce both PAEC apoptosis as well as PASMC proliferation, two hallmark pathologic events in PAH vasculopathy.

Because $\mathrm{LTB}_{4}$-secreting macrophages were contiguous with diseased arterioles, we hypothesized that inhibiting $\mathrm{LTB}_{4}$ signaling might be an effective treatment for $\mathrm{PH}$. Bestatin [(2S, 3R)-3-amino-2-hydroxy-4-phenylbutanoyl---leucine] is a well-tolerated $\mathrm{LTA}_{4} \mathrm{H}$ inhibitor that blocks $\mathrm{LTB}_{4}$ formation [61, 62]. In our rat models, bestatin treatment started as late as 3 weeks after SU administration (when PH is severe and animals are near death from their cardiopulmonary disease), subsequently reduced serum $\mathrm{LTB}_{4}$ levels, prevented PAEC injury, restored Sphk1-eNOS signaling, and rescued the animals from death. Since bestatin is known to exert pharmacological actions other than $\mathrm{LTA}_{4} \mathrm{H}$ inhibition [63, 64], we also tested a different $\mathrm{LTA}_{4} \mathrm{H}$ inhibitor (JNJ-26993135) [65, 66] and a BLT1 antagonist (LY293111) [67, 68]. Treatment with both of these agents also reversed PH and prevented PH-related death. While bestatin was also effective with reversing MCT-induced PH, it was ineffective in the SU-chronic hypoxia model which is consistent with the notion that different $\mathrm{PH}$ pathophysiologies can emerge from different disease triggers, and results can vary in hosts with different genetic backgrounds.

To determine the clinical relevance of $\mathrm{LTB}_{4}$ in human $\mathrm{PAH}$, we examined the expression of $\mathrm{LTA}_{4} \mathrm{H}$ in the lung tissue of $\mathrm{PAH}$ patients. In five out of six samples, $\mathrm{LTA}_{4} \mathrm{H}$ expression was notably elevated in macrophages that were clustered around occluded vessels and in the 
endothelial cells lining the lumen of the plexiform lesions. The fact that $\mathrm{LTA}_{4} \mathrm{H}$ was seen in both macrophages and endothelial cells in advanced disease (as opposed to being principally localized in macrophages early in disease) upregulation of both direct and transcellular synthetic pathways; it is possible that in addition to $\mathrm{LTB}_{4}$ being directly secreted by macrophages, $\mathrm{LTA}_{4}$ was also secreted by these cells, and this LT was taken up in PAECs (which are poor $\mathrm{LTA}_{4}$-producers) and converted in these increasingly abnormal occlusive intimal cells into $\mathrm{LTB}_{4}[69]$. Also, the serum concentration of $\mathrm{LTB}_{4}$ was significantly elevated in PAH patients, especially in those with connective tissue disease-associated PAH (CTD-PAH). By contrast, six of eight patients with idiopathic PAH appeared to have normal $\mathrm{LTB}_{4}$ levels. One explanation for these heterogeneous findings is that CTDs, such as systemic lupus erythematosus and systemic sclerosis, exhibit significant defects in Treg function and number (more so than, perhaps, idiopathic $\mathrm{PAH}$ patients) that may facilitate the inappropriate activation of macrophages including increased $\mathrm{LTB}_{4}$ production [8, 70-72]. Thus, these new findings again lend support to the idea that different forms of PAH likely have unique pathogenic mechanisms [73, 74].

\section{CysLTs in PAH}

CysLTs are known to cause hypoxic pulmonary vasoconstriction [75], bronchoconstriction [76, 77], decreased lung compliance, and pulmonary edema [77]. The role of Cys-LTs has been well studied in pulmonary airways disease, but little is known about their role in PAH. Elevated levels of CysLTs were first reported in neonates with hypoxemia and pulmonary hypertension in 1983 [78]. The concentrations of eicosanoids, specifically $\mathrm{TxB}_{2}, 6$-ketoPGF1a, $\mathrm{PGD}_{2}, \mathrm{PGE}_{2}, \mathrm{LTB}_{4}, \mathrm{LTC}_{4}$, and $\mathrm{LTE}_{4}$, in bronchoalveolar lavage fluid (BALF) and blood of infants with persistent $\mathrm{PH}$ were also reported to be markedly increased.

Furthermore, increased eicosanoids concentration correlated with poor clinical outcome of persistent pulmonary hypertension [79]. The continuing study of CysLTs in the airways may lend further insights into their role in the development of persistent $\mathrm{PH}$ as well as PAH.

\section{Conclusions}

This article has highlighted the growing information concerning how LTs may be participating in the development of certain forms of PAH. PAH remains an incurable and progressive disease. The last few decades have yielded a significantly deeper understanding of the pathobiology of PAH and have led to pharmacological advances, but there are challenges associated with these treatments, including the delivery systems, toxicity, frequent dosing schedules, variable efficacy, and cost [80]. Importantly, targeted immunotherapy as an adjuvant approach to current standard-of-care vasodilators has yet to be implemented. Anti-LT treatments may prove an effective complementary therapy for a subset of these patients.

\section{References}

1. Benza RL, Miller DP, Gomberg-Maitland M, Frantz RP, Foreman AJ, Coffey CS, Frost A, Barst RJ, Badesch DB, Elliott CG, et al. Predicting survival in pulmonary arterial hypertension: insights from the registry to evaluate early and long-term pulmonary arterial hypertension disease management (REVEAL). Circulation. 2010; 122(2):164-72. [PubMed: 20585012] 
2. Rubin LJ. Primary pulmonary hypertension. N Engl J Med. 1997; 336(2):111-7. [PubMed: 8988890]

3. Rubin LJ. Pathology and pathophysiology of primary pulmonary hypertension. Am J Cardiol. 1995; 75(3):51A-4A.

4. Barst RJ, McGoon M, Torbicki A, Sitbon O, Krowka MJ, Olschewski H, Gaine S. Diagnosis and differential assessment of pulmonary arterial hypertension. J Am Coll Cardiol. 2004; 43(12 Suppl S):40S-7S. [PubMed: 15194177]

5. Schermuly RT, Ghofrani HA, Wilkins MR, Grimminger F. Mechanisms of disease: pulmonary arterial hypertension. Nat Rev Cardiol. 2011; 8(8):443-55. [PubMed: 21691314]

6. Hassoun PM, Mouthon L, Barbera JA, Eddahibi S, Flores SC, Grimminger F, Jones PL, Maitland ML, Michelakis ED, Morrell NW, et al. Inflammation, growth factors, and pulmonary vascular remodeling. J Am Coll Cardiol. 2009; 54(1 Suppl):S10-9. [PubMed: 19555853]

7. Nicolls MR, Taraseviciene-Stewart L, Rai PR, Badesch DB, Voelkel NF. Autoimmunity and pulmonary hypertension: a perspective. Eur Respir J. 2005; 26(6):1110-8. [PubMed: 16319344]

8. Taraseviciene-Stewart L, Nicolls MR, Kraskauskas D, Scerbavicius R, Burns N, Cool C, Wood K, Parr JE, Boackle SA, Voelkel NF. Absence of T cells confers increased pulmonary arterial hypertension and vascular remodeling. Am J Respir Crit Care Med. 2007; 175(12):1280-9. [PubMed: 17413127]

9. Peters-Golden M, Henderson WR Jr. Leukotrienes. New Engl J Med. 2007; 357(18):1841-54. [PubMed: 17978293]

10. Peters-Golden M, Canetti C, Mancuso P, Coffey MJ. Leukotrienes: underappreciated mediators of innate immune responses. J Immunol. 2005; 174(2):589-94. [PubMed: 15634873]

11. Peters-Golden M, Brock TG. 5-lipoxygenase and FLAP. Prostaglandins Leukot Essent Fatty Acids. 2003; 69(2-3):99-109. [PubMed: 12895592]

12. Peters-Golden M, Brock TG. Intracellular compartmentalization of leukotrienebiosynthesis. AmJRespirCritCareMed. 2000; 161(2Pt2):S36-40.

13. Samuelsson B, Funk CD. Enzymes involved in the biosynthesis of leukotriene B4. J Biol Chem. 1989; 264(33):19469-72. [PubMed: 2555321]

14. Fitzpatrick FA, Liggett WF, Wynalda MA. Albumin-eicosanoid interactions. A model system to determine their attributes and inhibition. J Biol Chem. 1984; 259(5):2722-7. [PubMed: 6698991]

15. Yokomizo T, Uozumi N, Takahashi T, Kume K, Izumi T, Shimizu T. Leukotriene A4 hydrolase and leukotriene B4 metabolism. J Lipid Mediat Cell Signal. 1995; 12(2-3):321-32. [PubMed: 8777576]

16. Shimizu T, Izumi T, Seyama Y, Tadokoro K, Radmark O, Samuelsson B. Characterization of leukotriene A4 synthase from murine mast cells: evidence for its identity to arachidonate 5lipoxygenase. Proc Natl Acad Sci USA. 1986; 83(12):4175-9. [PubMed: 3012557]

17. Izumi T, Minami M, Ohishi N, Bito H, Shimizu T. Site-directed mutagenesis of leukotriene A4 hydrolase: distinction of leukotriene A4 hydrolase and aminopeptidase activities. J Lipid Mediat. 1993; 6(1-3):53-8. [PubMed: 8358013]

18. Minami M, Ohno S, Kawasaki H, Radmark O, Samuelsson B, Jornvall H, Shimizu T, Seyama Y, Suzuki K. Molecular cloning of a cDNA coding for human leukotriene A4 hydrolase. Complete primary structure of an enzyme involved in eicosanoid synthesis. J Biol Chem. 1987; 262(29): 13873-6. [PubMed: 3654641]

19. Shimizu T, Izumi T, Ohishi N, Seyama Y, Kitamura S. Biosynthesis and further transformations of leukotriene A4. Adv Prostaglandin Thromboxane Leukot Res. 1987; 17A:64-8. [PubMed: 2821769]

20. Hammerstrom S, Samuelsson B. Detection of leukotriene A4 as an intermediate in the biosynthesis of leukotrienes C4 and D4. FEBS Lett. 1980; 122(1):83-6. [PubMed: 6260529]

21. Funk CD. Prostaglandins and leukotrienes: advances in eicosanoid biology. Science. 2001; 294(5548):1871-5. [PubMed: 11729303]

22. Radmark O, Malmsten C, Samuelsson B. Leukotriene A4: enzymatic conversion to leukotriene C4. Biochem Biophys Res Commun. 1980; 96(4):1679-87. [PubMed: 6255951]

23. Orning L, Hammarstrom S. Inhibition of leukotriene C and leukotriene D biosynthesis. J Biol Chem. 1980; 255(17):8023-6. [PubMed: 6106018] 
24. Malmsten CL, Palmblad J, Uden AM, Radmark O, Engstedt L, Samuelsson B. Leukotriene B4: a highly potent and stereospecific factor stimulating migration of polymorphonuclear leukocytes. Acta Physiol Scand. 1980; 110(4):449-51. [PubMed: 6263048]

25. Sha' afi RI, Naccache PH, Molski TF, Borgeat P, Goetzl EJ. Cellular regulatory role of leukotriene B4: its effects on cation homeostasis in rabbit neutrophils. J Cell Physiol. 1981; 108(3):401-8. [PubMed: 6270168]

26. Henderson WR, Jorg A, Klebanoff SJ. Eosinophil peroxidase-mediated inactivation of leukotrienes B4, C4, and D4. J Immunol. 1982; 128(6):2609-13. [PubMed: 6281334]

27. Czarnetzki BM. Is eosinophil chemotactic factor identical with leukotriene B? Int Arch Allergy Appl Immunol. 1982; 67(2):181-3. [PubMed: 6276308]

28. Jorg A, Henderson WR, Murphy RC, Klebanoff SJ. Leukotriene generation by eosinophils. J Exp Med. 1982; 155(2):390-402. [PubMed: 6120203]

29. Murphy RC, Mathews WR. Purification and characterization of leukotrienes from mastocytoma cells. Methods Enzymol. 1982; 86:409-16. [PubMed: 6290843]

30. Holgate ST, Church MK. Control of mediator release from mast cells. Clin Allergy. 1982; 12(Suppl):5-13. [PubMed: 6183025]

31. Hsueh W, Sun FF. Leukotriene B4 biosynthesis by alveolar macrophages. Biochem Biophys Res Commun. 1982; 106(4):1085-91. [PubMed: 6288038]

32. Doig MV, Ford-Hutchinson AW. The production and characterisation of products of the lipoxygenase enzyme system released by rat peritoneal macrophages. Prostaglandins. 1980; 20(6): 1007-19. [PubMed: 6259695]

33. Fels AO, Pawlowski NA, Cramer EB, King TK, Cohn ZA, Scott WA. Human alveolar macrophages produce leukotriene B4. Proc Natl Acad Sci USA. 1982; 79(24):7866-70. [PubMed: 6296853]

34. Hui Y, Funk CD. Cysteinyl leukotriene receptors. Biochem Pharmacol. 2002; 64(11):1549-57. [PubMed: 12429344]

35. Yokomizo T, Masuda K, Kato K, Toda A, Izumi T, Shimizu T. Leukotriene B4 receptor. Cloning and intracellular signaling. Am J Respir Crit Care Med. 2000; 161(2 Pt 2):S51-5. [PubMed: 10673227]

36. Izumi T, Yokomizo T, Igarashi T, Shimizu T. Molecular cloning and characterization of leukotriene B4 receptor. Adv Exp Med Biol. 1999; 469:237-44. [PubMed: 10667336]

37. Crooke ST, Mattern M, Sarau HM, Winkler JD, Balcarek J, Wong A, Bennett CF. The signal transduction system of the leukotriene D4 receptor. Trends Pharmacol Sci. 1989; 10(3):103-7. [PubMed: 2556821]

38. Cristol JP, Provencal B, Sirois P. Leukotriene receptors. J Recept Res. 1989; 9(4-5):341-67. [PubMed: 2556577]

39. Metters KM. Leukotriene receptors. J Lipid Mediat Cell Signal. 1995; 12(2-3):413-27. [PubMed: 8777583]

40. Lipworth BJ. Leukotriene-receptor antagonists. Lancet. 1999; 353(9146):57-62. [PubMed: 10023966]

41. Voelkel NF, Tuder RM, Wade K, Hoper M, Lepley RA, Goulet JL, Koller BH, Fitzpatrick F. Inhibition of 5-lipoxygenase-activating protein (FLAP) reduces pulmonary vascular reactivity and pulmonary hypertension in hypoxic rats. J Clin Invest. 1996; 97(11):2491-8. [PubMed: 8647941]

42. Wright L, Tuder RM, Wang J, Cool CD, Lepley RA, Voelkel NF. 5-Lipoxygenase and 5lipoxygenase activating protein (FLAP) immunoreactivity in lungs from patients with primary pulmonary hypertension. Am J Respir Crit Care Med. 1998; 157(1):219-29. [PubMed: 9445303]

43. Jones JE, Walker JL, Song Y, Weiss N, Cardoso WV, Tuder RM, Loscalzo J, Zhang YY. Effect of 5-lipoxygenase on the development of pulmonary hypertension in rats. Am J Physiol Heart Circ Physiol. 2004; 286(5):H1775-84. [PubMed: 14726295]

44. Runo JR, Vnencak-Jones CL, Prince M, Loyd JE, Wheeler L, Robbins IM, Lane KB, Newman JH, Johnson J, Nichols WC, et al. Pulmonary veno-occlusive disease caused by an inherited mutation in bone morphogenetic protein receptor II. Am J Respir Crit Care Med. 2003; 167(6):889-94. [PubMed: 12446270] 
45. Aldred MA, Vijayakrishnan J, James V, Soubrier F, Gomez-Sanchez MA, Martensson G, Galie N, Manes A, Corris P, Simonneau G, et al. BMPR2 gene rearrangements account for a significant proportion of mutations in familial and idiopathic pulmonary arterial hypertension. Hum Mutat. 2006; 27(2):212-3. [PubMed: 16429403]

46. Newman JH, Trembath RC, Morse JA, Grunig E, Loyd JE, Adnot S, Coccolo F, Ventura C, Phillips JA 3rd, Knowles JA, et al. Genetic basis of pulmonary arterial hypertension: current understanding and future directions. J Am Coll Cardiol. 2004; 43(12 Suppl S):33S-9S. [PubMed: 15194176]

47. Takahashi H, Goto N, Kojima Y, Tsuda Y, Morio Y, Muramatsu M, Fukuchi Y. Downregulation of type II bone morphogenetic protein receptor in hypoxic pulmonary hypertension. Am J Physiol Lung Cell Mol Physiol. 2006; 290(3):L450-8. [PubMed: 16361357]

48. Song Y, Jones JE, Beppu H, Keaney JF Jr, Loscalzo J, Zhang YY. Increased susceptibility to pulmonary hypertension in heterozygous BMPR2-mutant mice. Circulation. 2005; 112(4):553-62. [PubMed: 16027259]

49. Radmark O, Samuelsson B. Regulation of the activity of 5-lipoxygenase, a key enzyme in leukotriene biosynthesis. Biochem Biophys Res Commun. 2010; 396(1):105-10. [PubMed: 20494120]

50. Werz O, Klemm J, Samuelsson B, Radmark O. 5-lipoxygenase is phosphorylated by p38 kinasedependent MAPKAP kinases. Proc Natl Acad Sci USA. 2000; 97(10):5261-6. [PubMed: 10779545]

51. Radmark O, Samuelsson B. 5-Lipoxygenase: mechanisms of regulation. J Lipid Res. 2009; 50(Suppl):S40-5. [PubMed: 18987389]

52. Werz O, Szellas D, Steinhilber D, Radmark O. Arachidonic acid promotes phosphorylation of 5lipoxygenase at Ser-271 by MAPK-activated protein kinase 2 (MK2). J Biol Chem. 2002; 277(17): 14793-800. [PubMed: 11844797]

53. Tabata T, Ono S, Song C, Noda M, Suzuki S, Tanita T, Fujimura S. Role of leukotriene B4 in monocrotaline-induced pulmonary hypertension. Nihon Kyobu Shikkan Gakkai Zasshi. 1997; 35(2):160-6. [PubMed: 9103852]

54. Tian W, Jiang X, Tamosiuniene R, Sung YK, Qian J, Dhillon G, Gera L, Farkas L, Rabinovitch M, Zamanian RT, et al. Blocking macrophage leukotriene b4 prevents endothelial injury and reverses pulmonary hypertension. Sci Transl Med. 2013; 5(200):200ra117.

55. Chalfant CE, Spiegel S. Sphingosine 1-phosphate and ceramide 1-phosphate: expanding roles in cell signaling. J Cell Sci. 2005; 118(Pt 20):4605-12. [PubMed: 16219683]

56. Wang L, Dudek SM. Regulation of vascular permeability by sphingosine 1-phosphate. Microvasc Res. 2009; 77(1):39-45. [PubMed: 18973762]

57. Rodriguez C, Gonzalez-Diez M, Badimon L, Martinez-Gonzalez J. Sphingosine-1-phosphate: a bioactive lipid that confers high-density lipoprotein with vasculoprotection mediated by nitric oxide and prostacyclin. Thromb Haemost. 2009; 101(4):665-73. [PubMed: 19350109]

58. Gonzalez-Diez M, Rodriguez C, Badimon L, Martinez-Gonzalez J. Prostacyclin induction by highdensity lipoprotein (HDL) in vascular smooth muscle cells depends on sphingosine 1-phosphate receptors: effect of simvastatin. Thromb Haemost. 2008; 100(1):119-26. [PubMed: 18612546]

59. Gude DR, Alvarez SE, Paugh SW, Mitra P, Yu J, Griffiths R, Barbour SE, Milstien S, Spiegel S. Apoptosis induces expression of sphingosine kinase 1 to release sphingosine-1-phosphate as a "come-and-get-me" signal. FASEB J. 2008; 22(8):2629-38. [PubMed: 18362204]

60. Heller EA, Liu E, Tager AM, Sinha S, Roberts JD, Koehn SL, Libby P, Aikawa ER, Chen JQ, Huang P, et al. Inhibition of atherogenesis in BLT1-deficient mice reveals a role for LTB4 and BLT1 in smooth muscle cell recruitment. Circulation. 2005; 112(4):578-86. [PubMed: 16043658]

61. Orning L, Krivi G, Fitzpatrick FA. Leukotriene A4 hydrolase. Inhibition by bestatin and intrinsic aminopeptidase activity establish its functional resemblance to metallohydrolase enzymes. J Biol Chem. 1991; 266(3):1375-8. [PubMed: 1846352]

62. Muskardin DT, Voelkel NF, Fitzpatrick FA. Modulation of pulmonary leukotriene formation and perfusion pressure by bestatin, an inhibitor of leukotriene A4 hydrolase. Biochem Pharmacol. 1994; 48(1):131-7. [PubMed: 8043014] 
63. Ota K, Kurita S, Yamada K, Masaoka T, Uzuka Y, Ogawa N. Immunotherapy with bestatin for acute nonlymphocytic leukemia in adults. Cancer Immunol Immunother. 1986; 23(1):5-10. [PubMed: 3533256]

64. Ota K, Uzuka Y. Clinical trials of bestatin for leukemia and solid tumors. Biotherapy. 1992; 4(3): 205-14. [PubMed: 1599804]

65. Rao NL, Dunford PJ, Xue X, Jiang X, Lundeen KA, Coles F, Riley JP, Williams KN, Grice CA, Edwards JP, et al. Anti-inflammatory activity of a potent, selective leukotriene A4 hydrolase inhibitor in comparison with the 5-lipoxygenase inhibitor zileuton. J Pharmacol Exp Ther. 2007; 321(3):1154-60. [PubMed: 17371808]

66. Whittle BJ, Varga C, Berko A, Horvath K, Posa A, Riley JP, Lundeen KA, Fourie AM, Dunford PJ. Attenuation of inflammation and cytokine production in rat colitis by a novel selective inhibitor of leukotriene A4 hydrolase. Br J Pharmacol. 2008; 153(5):983-91. [PubMed: 18157165]

67. Marder P, Spaethe SM, Froelich LL, Cerimele BJ, Petersen BH, Tanner T, Lucas RA. Inhibition of ex vivo neutrophil activation by oral LY293111, a novel leukotriene B4 receptor antagonist. Br J Clin Pharmacol. 1996; 42(4):457-64. [PubMed: 8904617]

68. Marder P, Sawyer JS, Froelich LL, Mann LL, Spaethe SM. Blockade of human neutrophil activation by 2-[2-propyl-3-[3-[2-ethyl-4-(4-fluorophenyl)-5- hydroxyphenoxy]propoxy]phenoxy] benzoic acid (LY293111), a novel leukotriene B4 receptor antagonist. Biochem Pharmacol. 1995; 49(11):1683-90. [PubMed: 7786309]

69. Feinmark SJ, Cannon PJ. Endothelial cell leukotriene C4 synthesis results from intercellular transfer of leukotriene A4 synthesized by polymorphonuclear leukocytes. J Biol Chem. 1986; 261(35):16466-72. [PubMed: 3023351]

70. Tamosiuniene R, Nicolls MR. Regulatory T cells and pulmonary hypertension. Trends Cardiovasc Med. 2011; 21(6):166-71. [PubMed: 22814424]

71. Tamosiuniene R, Tian W, Dhillon G, Wang L, Sung YK, Gera L, Patterson AJ, Agrawal R, Rabinovitch M, Ambler K, et al. Regulatory T cells limit vascular endothelial injury and prevent pulmonary hypertension. Circ Res. 2011; 109(8):867-79. [PubMed: 21868697]

72. Buckner JH. Mechanisms of impaired regulation by CD4(+)CD25(+)FOXP3(+) regulatory T cells in human auto-immune diseases. Nat Rev Immunol. 2010; 10(12):849-59. [PubMed: 21107346]

73. Rubin LJ. Treatment of pulmonary arterial hypertension due to scleroderma: challenges for the future. Rheum Dis Clin North Am. 2008; 34(1):191-7. viii. [PubMed: 18329540]

74. Chin KM, Rubin LJ. Pulmonary arterial hypertension. J Am Coll Cardiol. 2008; 51(16):1527-38. [PubMed: 18420094]

75. Smedegard G, Hedqvist P, Dahlen SE, Revenas B, Hammarstrom S, Samuelsson B. Leukotriene C4 affects pulmonary and cardiovascular dynamics in monkey. Nature. 1982; 295(5847):327-9. [PubMed: 6799832]

76. Weiss JW, Drazen JM, Coles N, McFadden ER Jr, Weller PF, Corey EJ, Lewis RA, Austen KF. Bronchoconstrictor effects of leukotriene C in humans. Science. 1982; 216(4542):196-8. [PubMed: 7063880]

77. Hanna CJ, Bach MK, Pare PD, Schellenberg RR. Slow-reacting substances (leukotrienes) contract human airway and pulmonary vascular smooth muscle in vitro. Nature. 1981; 290(5804):343-4. [PubMed: 6111025]

78. Stenmark KR, James SL, Voelkel NF, Toews WH, Reeves JT, Murphy RC. Leukotriene C4 and D4 in neonates with hypoxemia and pulmonary hypertension. New Engl J Med. 1983; 309(2):7780. [PubMed: 6855869]

79. Dobyns EL, Wescott JY, Kennaugh JM, Ross MN, Stenmark KR. Eicosanoids decrease with successful extracorporeal membrane oxygenation therapy in neonatal pulmonary hypertension. Am J Respir Crit Care Med. 1994; 149(4 Pt 1):873-80. [PubMed: 8143049]

80. Dingemanse J, Sidharta PN, Maddrey WC, Rubin LJ, Mickail H. Efficacy, safety and clinical pharmacology of macitentan in comparison to other endothelin receptor antagonists in the treatment of pulmonary arterial hypertension. Expert Opin Drug Saf. 2013 doi: $10.1517 / 14740338.2014 .859674$. 


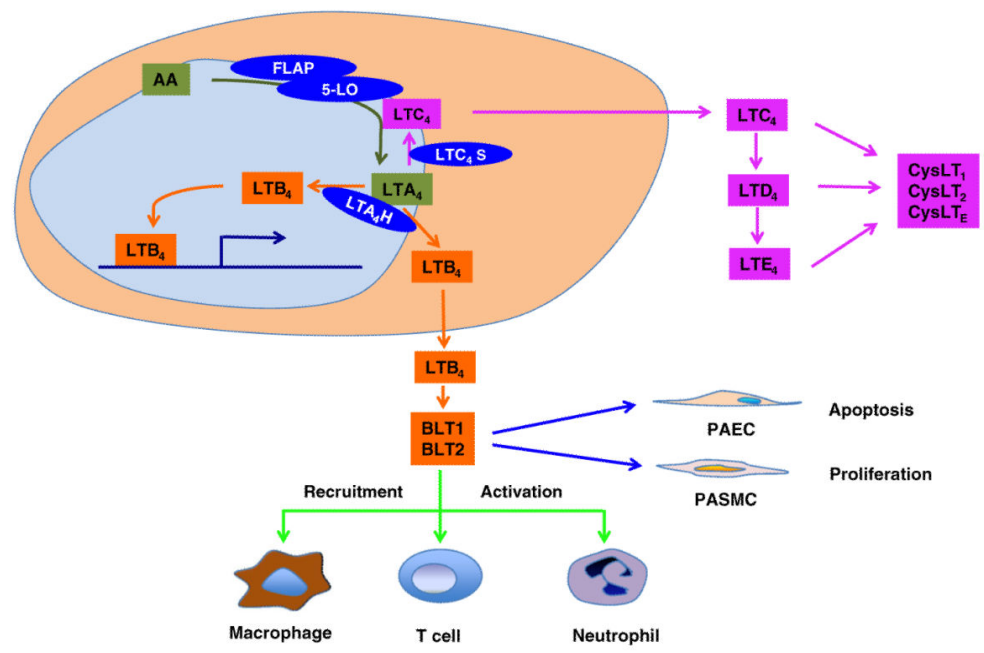

Fig. 1.

LT pathways and functions in PAH. LTs are synthesized from the arachidonic acid (AA) pathway, where 5-LO works together with FLAP on the perinuclear membrane that converts AA to $\mathrm{LTA}_{4}$. $\mathrm{LTA}_{4}$ is quickly metabolized to $\mathrm{LTB}_{4}$ by $\mathrm{LTA}_{4} \mathrm{H}$, or is converted to $\mathrm{LTC}_{4}$ by $\mathrm{LTC}_{4} \mathrm{~S}$. $\mathrm{LTC}_{4}$ undergoes sequential peptide cleavage of the glutathione moiety to form $\mathrm{LTD}_{4}$ or $\mathrm{LTE}_{4}$. $\mathrm{LTB}_{4}$ may function as a transcriptional regulator in the nucleus or is transported out from the source cell and binding to its cognate receptors (BLT1 and BLT2) to initiate the downstream signaling. In $\mathrm{PAH}$, elevated $\mathrm{LTB}_{4}$ signaling around the disease arteriole results in the recruitment of the leukocytes. Recent data demonstrate that $\mathrm{LTB}_{4}$ may also cause vascular remodeling by inducing the PAEC apoptosis and PASMC proliferation 